\title{
NASA's WATER RESOURCES ELEMENT WITHIN THE APPLIED SCIENCES PROGRAM
}

\author{
David Toll $^{1}$, Bradley Doorn ${ }^{2}$, Edwin Engman ${ }^{3}$ \\ 1- NASA/Goddard Space Flight Center, 2- NASA/Headquarters, \\ 3- Science \& Applications International Corporation
}

\section{ABSTRACT}

The NASA Applied Sciences Program works within NASA Earth sciences to leverage investment of satellite and information systems to increase the benefits to society through the widest practical use of NASA research results. Such observations provide a huge volume of valuable data in both near-real-time and extended back nearly 50 years about the Earth's land surface conditions such as land cover type, vegetation type and health, precipitation, snow, soil moisture, and water levels and radiation. Observations of this type combined with models and analysis enable satellite-based assessment of numerous water resources management activities. The primary goal of the Earth Science Applied Science Program is to improve future and current operational systems by infusing them with scientific knowledge of the Earth system gained through space-based observation, model results, and development and deployment of enabling technologies, systems, and capabilities. Water resources is one of eight elements in the Applied Sciences Program and it addresses concerns and decision making related to water quantity and water quality.

With increasing population pressure and water usage coupled with climate variability and change, water issues are being reported by numerous groups as the most critical environmental problems facing us in the $21^{\text {st }}$ century. Competitive uses and the prevalence of river basins and aquifers that extend across boundaries engender political tensions between communities, stakeholders and countries. Mitigating these conflicts and meeting water demands requires using existing resources more efficiently. The potential crises and conflicts arise when water is 
competed among multiple uses. For example, urban areas, environmental and recreational uses, agriculture, and energy production compete for scarce resources, not only in the Western U.S. but throughout much of the U.S. but also in many parts of the world. In addition to water availability issues, water quality related problems are seriously affecting human health and our environment. The NASA Water Resources Program Element works to use NASA products to address these critical issues.

The goal of the Water Resources Program is to encourage water management organizations to use Earth science data, models, technology and other capabilities in their decision support tools for problem solving related to water resource management The NASA Water Resources Program organizes its projects under five functional themes.

1) Streamflow and Flood Forecasting

2) Water Supply and Irrigation (Includes evapotranspiration)

3) Drought

4) Water Quality

5) Climate and Water Resources

We will illustrate ongoing NASA Water Resources application projects evaluating and benchmarking the use of NASA products primarily within the context of end users decision support systems. To maximize this activity NASA Water Resources Program works closely with other government agencies (e.g., the National Oceanic and Atmospheric Administration (NOAA); the U.S. Department of Agriculture (USDA) Foreign Agricultural Service (FAS); the U.S. Geological Survey (USGS); the Air Force Weather Agency (AFWA)), universities, and non-profit, international, and private sector organizations. Examples of the types of NASA contributions to the water management community include such possibilities as:

- Using satellite observations to estimate hydrologic variables, i.e., snow water equivalent, soil moisture, aquifer volumes, reservoir storages, etc.

- Model derived products, i.e., evapotranspiration, precipitation, runoff, ground water recharge, and other data assimilation products, etc. 
- Water quality, i.e., improved inputs from NASA models and satellite observations to nonpoint source models, turbidity, temperature, etc.

Activities in the Applied Sciences Program are carried out through competitive grants that are peer reviewed to insure that they are technically feasible and address high priority Program goals. This paper uses examples to describe the Water Resources Applied Sciences Program and the potential opportunities for using NASA science products for problem solving. The paper also describes how governmental, private and academic organizations can participate and compete for NASA support to enhance their problem solving mandates.

\section{BIBLIOGRAPHY}

Allen, A., J. Hendrickx, D. Toll, M. Anderson, and J. Kleissl, From High Overhead: ET Measurement via Remote Sensing, Southwest Hydrology Magazine, Jan-Feb. edition, htp:/ www.swhydro.arizona.edu, 2008.

Department of State Water for the Poor Act, 4th Annual Report, P.L. 109-121, Department of State, http://www.state.gov/documents/organization/125643.pdf, 2009.

De Goncalves, G.G., E. Burke, W. Shuttleworth, P. Houser, D. Toll, M. Rodell and K. Arsenault, Towards a South American Land Data Assimilation System (SALDAS): Aspects of Land Surface Model Spin-Up Using the Simplified Simple Biosphere (SSIB), J. Geophys. Res., 111, D17110, doi:10.1029/2005JD006297, 2006

De Goncalves, L.G.G., W.J. Shuttleworth, E. Larroza, D. Vila, M.J. Bottino, D.L. Toll, D.L. Herdies, J.A. Aravequia, J.G.Z. de Mattos, M. Rodell and P. Houser, The South American Land Data Assimilation System (SALDAS) 5-Year Retrospective Atmospheric Forcing Datasets, J. Hydrometeorology, V10 (4), 999-1010, 2009.

Kumar, S.V., C.D. Peters-Lidard, Y. Tian, P.R. Houser, J. Geiger, S. Olden, L. Lighty, J.L. Eastman, B. Doty, P. Dirmeyer, J. Adams, K. Mitchell, E. F. Wood and J. Sheffield, Land Information System - An Interoperable Framework for High Resolution Land Surface Modeling. Environmental Modelling \& Software, 21:1402-1415, 2006.

Lee, S., W. Ni-Meister, D. Toll, T. Engman, J. Nigro, and A. Gutierrez-Magness. Assessing the Hydrologic Performance of the EPA's Nonpoint Source Water Quality Assessment Decision Support Tool Using NASA Satellite Observations and Land Surface Models, in press, 2010. 
Nigro, J., D. Toll, E. Partington, W. Ni-Meister, S. Lee, A.Magness, T. Engman, and K. Arsenault, NASA-modified Precipitation Products to Improve EPA Nonpoint Source Water Quality Modeling for the Chesapeake Bay, Journal Environmental Quality, in review, 2010.

Ozdogan, M., Rodell, M., Kato, H., and Toll, D.L., Impact of Irrigation on LDAS Predicted States and Hydrological Fluxes, J. Hydrometeorology, in press, 2008

Rodell, M., P. R. Houser, U. Jambor, J. Gottschalck, K. Mitchell, C.-J. Meng, K. Arsenault, B. Cosgrove, J. Radakovich, M. Bosilovich, J. K. Entin, J. P. Walker, D. Lohmann, and D. Toll, The Global Land Data Assimilation System, Bull. Amer. Meteor. Soc., 85 (3), 381394, 2004.

Toll, D., L. Friedl, E. Engman, K. Arsenault, and J. Nigro, Opportunities for the Water Resources Community to Participate in NASA's Applied Sciences Program, Universities Council on Water Resources, Annual Conference, Increasing Freshwater Supplies, July 18-20, Santa Fe, New Mexico, Technical Presentation and Technical paper (4 pp.), 2006

Toll, D., K. Arsenault, E. Engman, L. Friedl, C. Peters-Lidard, Ana Pinheiro, J. Nigro, J. 2006. Protect and Monitor Water Resources 2006. IGARRS Annual Meeting, Denver, CO (July/Aug), Technical Paper (4pp) and Technical Presentation, 2006.

Toll, D., Engman, E. Partington, A. Magness, P. Townsend, W. Ni-Meister, 2008. Benchmark Report for the EPA Decision Support Tool, NASA Benchmark Report. http//wmp.gsfc.nasa.gov/reports/BenchRpt BASINS-10-7-08.pdf.

Vila, D., L.G.G. de Goncalves, D.L. Toll and J.R. Rozante,: Statistical Evaluation of Combined Daily Gauge Observations and Rainfall Satellite Estimations over Continental South America, J. Hydrometeorology, Vol 10 (2), 533-543, 2009. 